\author{
LESZEK BIELECKI
}

ORCID: 0000-0002-1553-1141

Uniwersytet Jana Kochanowskiego w Kielcach lbielecki@ujk.edu.pl

\title{
Decyzja w sprawie skutków podatkowych transakcji w projekcie nowelizacji ustawy Ordynacja podatkowa, interpretacja indywidualna w Ordynacji podatkowej a decyzja $\mathrm{w}$ sprawie interpretacji indywidualnej z ustawy Prawo przedsiębiorców
}

\begin{abstract}
Abstrakt: Przedmiotowe opracowanie omawia trzy zagadnienia: decyzję w sprawie skutków podatkowych transakcji w projekcie nowelizacji ustawy Ordynacja podatkowa, interpretację indywidualną w Ordynacji podatkowej i decyzję w sprawie interpretacji indywidualnej z ustawy Prawo przedsiębiorców. Wspólną cechą omawianych instytucji prawnych jest niezależność — każda z nich funkcjonuje osobno i charakteryzuje się samodzielnością proceduralną. Inną wspólną cechą jest cel tychże rozwiązań prawnych.

W konkluzji pojawia się potrzeba ponownej analizy przydatności i funkcjonalności obowiązujących unormowań prawnych i wysnucia wniosków de lege ferenda w kierunku zinstytucjonalizowania interpretacji indywidualnych w jednym ośrodku. W tym zakresie pojawiają się cztery istotne pytania: jaki miałby być zakres interpretacji, jakich dziedzin prawa miałby dotyczyć, jak miałby być zorganizowany oraz jaką gwarantowałby ochronę dla wnioskodawcy. Omawiane zagadnienie w określonej części z całą pewnością dotyczy relacji oraz stosunku państwa do przedsiębiorcy i stanowi wyzwanie dla praktyki i nauki.
\end{abstract}

Słowa kluczowe: decyzja w sprawie skutków podatkowych transakcji, Ordynacja podatkowa, interpretacja indywidualna, decyzja w sprawie interpretacji indywidualnej, ustawa Prawo przedsiębiorców. 


\section{Wstęp}

W procedurze załatwiania spraw związanych z działalnością gospodarczą w ustawie Prawo przedsiębiorców ${ }^{1}$ w art. 34 i 35 funkcjonuje instytucja tak zwanej interpretacji indywidualnej. Interpretacja indywidualna to urzędowe wyjaśnienie w sprawie zakresu i sposobu stosowania przepisów, z których wynika obowiązek świadczenia przez przedsiębiorcę daniny publicznej bądź składek na ubezpieczenia społeczne lub zdrowotne w jego indywidualnej sprawie. Wniosek o wydanie interpretacji może dotyczyć zaistniałego stanu faktycznego lub zdarzeń przyszłych. Ponadto w zakresie interpretacji indywidualnej funkcjonuje tak zwana utrwalona praktyka interpretacyjna.

Natomiast w projekcie ustawy Ordynacja podatkowa ${ }^{2}$ w art. 534-544 funkcjonuje instytucja tak zwanej konsultacji skutków podatkowych transakcji. Stosownie do art. 534 projektu Ordynacji podatkowej organ podatkowy pierwszej instancji na wniosek zainteresowanego i po przeprowadzeniu z nim konsultacji wydaje decyzję $\mathrm{w}$ sprawie skutków podatkowych w zakresie danego podatku i transakcji, zwaną dalej „decyzją w sprawie skutków podatkowych”, dotyczącą czynności lub zdarzeń, których dokonywał lub w których brał udział zainteresowany, zwanych dalej w tym tekście „transakcjami”. W ramach tejże procedury wnioskodawca oraz organ podatkowy będą mogli w trybie konsultacji dokonać uzgodnień dotyczących skutków podatkowych dokonanych przez wnioskodawcę czynności jeszcze przed zaistnieniem potencjalnego sporu.

W ustawie Ordynacja podatkowa funkcjonuje również instytucja interpretacji indywidualnej. Zgodnie bowiem z art. 14b tejże ustawy dyrektor Krajowej Informacji Skarbowej, na wniosek zainteresowanego, wydaje — w jego indywidualnej sprawie - interpretację przepisów prawa podatkowego (interpretację indywidualną). Ponadto zgodnie z art. 14j Ordynacji podatkowej, stosownie do swojej właściwości, interpretacje indywidualne wydaje wójt, burmistrz (prezydent miasta), starosta lub marszałek województwa.

W tym przedmiotowym opracowaniu podejmę próbę analizy relacji i ewentualnych współzależności pomiędzy decyzją w sprawie skutków podatkowych transakcji przewidzianą $\mathrm{w}$ projekcie nowelizacji ustawy Ordynacja podatkowa a decyzją w sprawie interpretacji indywidualnej przewidzianą w obowiązującej ustawie Prawo przedsiębiorców oraz postanowieniem z tejże ustawy w sprawie interpretacji indywidualnej przepisów prawa podatkowego.

${ }^{1}$ Ustawa z dnia 6 marca 2018 roku — Prawo przedsiębiorców (tekst jedn. Dz.U. z 2018 r. poz. $646 \mathrm{ze} \mathrm{zm}$.).

2 S. Babiarz et al., Nowa Ordynacja podatkowa. Z prac Komisji Kodyfikacyjnej Ogólnego Prawa Podatkowego, Białystok 2017, s. 655. Projekt ustawy Ordynacja podatkowa jest efektem prac odpowiedniej komisji powołanej rozporządzeniem Rady Ministrów z dnia 21 października 2014 roku w sprawie utworzenia, organizacji i trybu działania Komisji Kodyfikacyjnej Ogólnego Prawa Podatkowego (Dz.U. z 2014 r. poz. 1471 ze zm.). 


\section{Decyzja w sprawie skutków podatkowych transakcji w projekcie nowelizacji ustawy Ordynacja podatkowa}

Decyzja w sprawie skutków podatkowych może dotyczyć w szczególności transakcji, w których wyniku dochodzi do przeniesienia własności składników majątkowych lub przekazania ich do używania oraz udzielania pożyczek lub kredytów, a także realizacji procesów restrukturyzacyjnych lub wspólnych przedsięwzięć. Skutki muszą wystąpić przed złożeniem przez zainteresowanego wniosku o konsultację. Przedmiotowej decyzji nie można wydać w sprawach dotyczących transakcji, które w dniu złożenia wniosku o konsultację są przedmiotem postępowania podatkowego, kontroli podatkowej lub kontroli celno-skarbowej. Ponadto decyzja $\mathrm{w}$ tej sprawie nie może być wydana, jeśli transakcja jest przedmiotem porozumień w sprawach ustalania cen transakcyjnych oraz w sprawach tak zwanych opinii zabezpieczających. W wypadku natomiast wszczęcia $\mathrm{z}$ urzędu postępowania podatkowego w sprawie, w której został złożony wniosek o konsultację, żądanie zawarte we wniosku podlega rozpatrzeniu w tym postępowaniu, a postępowanie wszczęte wnioskiem ulega umorzeniu.

Przed złożeniem wniosku o konsultację zainteresowany może zwrócić się do organu podatkowego o wyjaśnienie wszelkich wątpliwości dotyczących przeprowadzenia konsultacji w jego indywidualnej sprawie. Do czasu wydania decyzji w sprawie skutków podatkowych wnioskodawca może zmienić swoje stanowisko co do skutków podatkowych transakcji, a przed wydaniem tej decyzji organ podatkowy doręcza wnioskodawcy projekt rozstrzygnięcia, wyznaczając mu czternastodniowy termin do wypowiedzenia się w sprawie tego projektu.

Decyzja w sprawie skutków podatkowych zawiera ocenę stanowiska wnioskodawcy co do skutków podatkowych transakcji wraz z uzasadnieniem faktycznym i prawnym. Jeżeli jednak w postępowaniu podatkowym organ podatkowy stwierdzi, że podatnik mimo ciążącego na nim obowiązku nie złożył deklaracji albo nie wykazał w niej zobowiązania podatkowego lub zaniżył wysokość zobowiązania podatkowego, jak też kiedy nie zapłacił podatku w całości lub w części bądź w przypadku konieczności wydania orzeczenia o braku zobowiązania, określeniu dochodu, przychodu lub zysku czy określeniu wysokości straty, a także określeniu prawidłowej wysokości kwoty zwrotu podatku lub nadwyżki podatku naliczonego nad należnym do odliczenia w następnych okresach rozliczeniowych - w decyzji w sprawie skutków podatkowych organ podatkowy dokonuje wymiaru w zakresie skutków podatkowych transakcji objętej wnioskiem o konsultację, lecz w uzasadnieniu tej decyzji informuje, że w pozostałym zakresie deklaracja wywołuje skutki prawne. W związku z tym przedmiotowa decyzja nie zawiera oceny stanowiska wnioskodawcy co do skutków podatkowych 
transakcji oraz uzasadnienia faktycznego i prawnego. W wypadku zaś uznania w ogóle stanowiska wnioskodawcy za nieprawidłowe przedmiotowa decyzja zawiera także wskazanie prawidłowego stanowiska wraz z uzasadnieniem faktycznym i prawnym. Ponadto jeżeli w toku postępowania organ stwierdzi, że wartość transakcji, która może być przedmiotem konsultacji, jest wyższa od podanej we wniosku, organ ten ustala wysokość tak zwanej opłaty uzupełniającej.

Postępowanie w sprawie wydania decyzji o skutkach podatkowych transakcji nie stoi na przeszkodzie i nie ogranicza możliwości późniejszego wydania w wyniku postępowania podatkowego decyzji wymiarowej w zakresie tego samego podatku oraz za rok podatkowy lub inny okres rozliczeniowy, którego dotyczy decyzja w sprawie skutków podatkowych. W decyzji wymiarowej organ podatkowy uwzględnia treść decyzji w sprawie skutków podatkowych, w tym dokonany w niej wymiar. Ponadto $\mathrm{z}$ dniem, w którym decyzja wymiarowa stanie się ostateczna, decyzja w sprawie skutków podatkowych wygasa w zakresie objętym decyzją wymiarową, na co organ podatkowy wskazuje w uzasadnieniu decyzji wymiarowej.

Na podstawie zaprezentowanej procedury wnioskodawca będzie mógł uzyskać wiążące potwierdzenie konsekwencji podatkowych zdarzeń lub procesów gospodarczych. W ramach tej procedury dokonywane są ustalenia faktyczne, prowadzi się postępowanie dowodowe, a w szczególności jest prowadzony dialog, czyli konsultacja wnioskodawcy z organem podatkowym, na przykład w kwestiach rodzaju i wartości transakcji czy poziomu stosowanych cen. Należy podkreślić, że w rezultacie stosowania tej procedury nastąpi wydanie władczego rozstrzygnięcia organu administracji podatkowej, jakim jest decyzja administracyjna. Warto jednak również podkreślić, że decyzja dotyczy transakcji związanej z konkretnym tytułem podatkowym i zapada w atmosferze konsensusu oraz uzgodnienia jej kształtu pomiędzy niejako dwiema stronami konsultacji (ale — co muszę podkreślić — nie negocjacji), czyli wnioskodawcy i organu podatkowego. Trzeba dodatkowo wskazać, że w odniesieniu do określonej transakcji będzie można prowadzić kilka postępowań jednocześnie i wydać kilka odrębnych decyzji w sprawie skutków podatkowych w różnych podatkach. Oczywiście organem właściwym w tym względzie jest zawsze organ pierwszej instancji, który wydaje decyzję $\mathrm{w}$ terminie przewidzianym $\mathrm{w}$ przepisach o postępowaniu podatkowym. Od decyzji służy środek zaskarżenia w postaci odwołania.

Wydaje się, że brzmienie przytoczonych przepisów wskazuje, że przewidywana procedura będzie wykorzystywana do oceny konsekwencji podatkowych transakcji o skomplikowanej strukturze, obarczonych dużym ryzykiem podatkowym dla podmiotów gospodarczych, czyli przykładowo zdarzeń związanych z restrukturyzacją, a więc łączeniem, przekształcaniem i podziałem spółek, albo wyceną wartości przedmiotu opodatkowania, czyli oceny charakteru przedmiotu transakcji. 


\section{Decyzja w sprawie interpretacji indywidualnej z ustawy Prawo przedsiębiorców}

Interpretacja indywidualna zawiera wyczerpujący opis przedstawionego we wniosku stanu faktycznego lub zdarzenia przyszłego oraz wskazanie prawidłowego stanowiska wraz z uzasadnieniem prawnym oraz pouczeniem o prawie wniesienia środka zaskarżenia. Udzielenie interpretacji następuje w formie decyzji, od której służy odwołanie. Interpretację indywidualną wydaje się bez zbędnej zwłoki, jednak nie później niż w terminie 30 dni od dnia wpływu do organu lub państwowej jednostki organizacyjnej kompletnego i opłaconego wniosku o wydanie interpretacji indywidualnej. W razie niewydania interpretacji $\mathrm{w}$ terminie uznaje się, że w dniu następującym po dniu, w którym upłynął termin wydania interpretacji, została wydana interpretacja indywidualna stwierdzająca prawidłowość stanowiska przedstawionego we wniosku o wydanie interpretacji.

Należy podkreślić, że podmiotem interpretacji w omawianym zakresie jest wyłącznie przedsiębiorca, który może złożyć wniosek o wydanie interpretacji do właściwego organu lub właściwej państwowej jednostki organizacyjnej. Należy także wskazać, że omawiana instytucja interpretacji indywidualnych nawiązuje do już obowiązujących w tym zakresie unormowań przewidzianych w ustawie Ordynacja podatkowa ${ }^{3}$. Przewidziana w Ordynacji podatkowej instytucja interpretacji indywidualnej prawa podatkowego jest możliwa do wykorzystania przez wszystkich podatników, w tym przedsiębiorców.

Interpretacja indywidualna nie jest jednak wiążąca dla przedsiębiorcy, z tym że przedsiębiorca nie może być obciążony sankcjami administracyjnymi, finansowymi lub karami w zakresie, w jakim zastosował się do uzyskanej interpretacji indywidualnej, ani daninami w wysokości wyższej niż wynikające z uzyskanej interpretacji indywidualnej. Interpretacja jest za to wiążąca dla organów lub państwowych jednostek organizacyjnych właściwych dla przedsiębiorcy i może zostać zmieniona wyłącznie w drodze wznowienia postępowania. Nie zmienia się interpretacji, w której wyniku nastąpiły nieodwracalne skutki prawne. Przedsiębiorca nie jest związany interpretacją i nie może być obciążony sankcjami w wypadku zastosowania się do tak zwanej utrwalonej praktyki interpretacyjnej właściwego organu lub jednostki organizacyjnej. Przez utrwaloną praktykę interpretacyjną należy rozumieć wyjaśnienia co do zakresu i sposobu zastosowania przepisów, z których wynika obowiązek świadczenia przez przedsiębiorcę daniny publicznej lub składek na ubezpieczenie społeczne lub zdrowotne, dominujące w wydawanych w takich samych stanach faktycznych oraz takim samym stanie prawnym $-\mathrm{w}$ trakcie danego okresu rozliczeniowego oraz

3 Ustawa z dnia 29 sierpnia 1997 roku — Ordynacja podatkowa (tekst jedn. Dz.U. z 2019 r. poz. 900). 
w okresie 12 miesięcy przed rozpoczęciem okresu rozliczeniowego - interpretacjach indywidualnych.

Należy zwrócić uwagę, że interpretacja indywidualna może zostać zmieniona tylko przy zastosowaniu zasadniczo nadzwyczajnego trybu wzruszania decyzji ostatecznych, jakim jest wznowienie postępowania. Ustawodawca nie przewidział w tym zakresie żadnego innego trybu lub sposobu postępowania, w przeciwieństwie do regulacji w zakresie interpretacji podatkowych, dzięki zastosowaniu którego można zmienić interpretacje prawa związane z działalnością gospodarczą. Zmiana przez wznowienie wymaga przy tym zastosowania przepisów o wznowieniu postępowania administracyjnego z art. 147 i następnych kodeksu postępowania administracyjnego ${ }^{4}$. Przepisy w tym zakresie mogą być zastosowane wobec decyzji ostatecznej, a ponadto jeśli zostanie stwierdzone występowanie co najmniej jednej z ośmiu przesłanek wznowienia postępowania. Dodatkowo instytucja wznowienia jest zasadniczo przewidziana dla spraw o wadliwym postępowaniu, a nie dla spraw, w których podważa się zasadność wydanej decyzji, jak na przykład przy stwierdzeniu nieważności decyzji ostatecznej. Istnieją również inne tryby kodeksu postępowania administracyjnego, które można by zastosować w tej sytuacji, chociażby instytucja uchylenia lub zmiany decyzji ostatecznej albo stwierdzenia nieważności decyzji ostatecznej. Wydaje się zatem, że takie rozwiązania prawne, przewidujące tylko jeden tryb do wzruszenia interpretacji ostatecznej, nie jest do końca prawidłowe ${ }^{5}$.

\section{Postanowienie w sprawie interpretacji indywidualnej z ustawy Ordynacja podatkowa}

Podobna instytucja interpretacji indywidualnych występuje na gruncie obowiązującej ustawy Ordynacja podatkowa. Zgodnie bowiem z brzmieniem art. 14b tejże ustawy dyrektor Krajowej Informacji Skarbowej, na wniosek zainteresowanego, wydaje - w jego indywidualnej sprawie — interpretację przepisów prawa podatkowego (interpretację indywidualną). Wniosek o interpretację indywidualną może dotyczyć zaistniałego stanu faktycznego lub zdarzeń przyszłych. Przedmiotem wniosku o interpretację indywidualną nie mogą być jednak przepisy prawa podatkowego: regulujące właściwość, uprawnienia i obowiązki organów podatkowych albo mające na celu przeciwdziałanie unikaniu opodatkowania, które odnoszą się do nadużycia przepisów prawa podatkowego, prowadzenia rzeczywistej

${ }^{4}$ Ustawa z dnia 14 czerwca 1960 roku - Kodeks postępowania administracyjnego (tekst jedn. Dz.U. z 2018 r. poz. 2096 ze zm.).

${ }^{5}$ L. Bielecki, Załatwianie spraw z zakresu działalności gospodarczej, [w:] Konstytucja biznesu. Komentarz, red. M. Wierzbowski, Warszawa 2019, s. 165-166. 
działalności gospodarczej lub podejmowania działań w sposób sztuczny lub bez uzasadnienia ekonomicznego.

Składający wniosek o wydanie interpretacji indywidualnej zobowiązany jest do wyczerpującego przedstawienia zaistniałego stanu faktycznego albo zdarzenia przyszłego oraz do przedstawienia własnego stanowiska w sprawie oceny prawnej tego stanu faktycznego albo zdarzenia przyszłego. Nie wydaje się interpretacji indywidualnej w zakresie tych elementów stanu faktycznego, które w dniu złożenia wniosku o interpretację są przedmiotem toczącego się postępowania podatkowego, kontroli podatkowej, kontroli celno-skarbowej albo gdy w tym zakresie sprawa została rozstrzygnięta co do jej istoty w decyzji lub postanowieniu organu podatkowego. Jeżeli przedstawione we wniosku stan faktyczny lub zdarzenie przyszłe odpowiadają zagadnieniu będącemu przedmiotem interpretacji ogólnej wydanej w takim samym stanie prawnym, wydaje się postanowienie o stwierdzeniu, że do stanu faktycznego lub zdarzenia przyszłego opisanych we wniosku ma zastosowanie interpretacja ogólna, z jednoczesnym stwierdzeniem bezprzedmiotowości wniosku. W tym wypadku w postanowieniu wskazuje się oznaczenie interpretacji ogólnej wraz z podaniem miejsca jej publikacji. Na wydane postanowienie przysługuje zażalenie.

Interpretacja indywidualna zawiera wyczerpujący opis przedstawionego we wniosku stanu faktycznego lub zdarzenia przyszłego oraz ocenę stanowiska wnioskodawcy wraz z uzasadnieniem prawnym tej oceny. Można odstąpić od uzasadnienia prawnego, jeżeli stanowisko wnioskodawcy jest prawidłowe w pełnym zakresie. W razie negatywnej oceny stanowiska wnioskodawcy interpretacja indywidualna zawiera wskazanie prawidłowego stanowiska wraz z uzasadnieniem prawnym. Interpretacja indywidualna zawiera pouczenie o treści art. 14na oraz o prawie wniesienia skargi do sądu administracyjnego. Interpretację indywidualną przepisów prawa podatkowego wydaje się bez zbędnej zwłoki, jednak nie później niż w terminie 3 miesięcy od dnia otrzymania wniosku. Interpretacja indywidualna może być uchylona lub zmieniona. Do interpretacji w kwestiach procesowych stosuje się przepisy o postępowaniu podatkowym z Ordynacji podatkowej.

Należy również pamiętać, że na gruncie ustawy Ordynacja podatkowa, stosownie do swojej właściwości, interpretacje indywidualne wydaje wójt, burmistrz (prezydent miasta), starosta lub marszałek województwa.

Nie można też zapominać, że zastosowanie się do interpretacji indywidualnej przed jej zmianą, stwierdzeniem jej wygaśnięcia lub przed doręczeniem organowi podatkowemu odpisu prawomocnego orzeczenia sądu administracyjnego uchylającego interpretację indywidualną nie może szkodzić wnioskodawcy, także w wypadku nieuwzględnienia jej w rozstrzygnięciu sprawy podatkowej. Zastosowanie się do interpretacji ogólnej przed jej zmianą nie może szkodzić temu, kto się do niej zastosował, również w przypadku nieuwzględnienia jej w rozstrzygnięciu sprawy podatkowej. W zakresie związanym z zastosowaniem się do interpretacji, która się zmieniła bądź której wygaśnięcie stwierdzono, lub interpretacji nieuwzględnionej w rozstrzygnięciu sprawy podatkowej nie wszczyna się postępowania w sprawach 
o przestępstwa skarbowe lub wykroczenia skarbowe, a postępowanie wszczęte w tych sprawach umarza się oraz nie nalicza odsetek za zwłokę.

Ponadto $\mathrm{z}$ wnioskiem o wydanie interpretacji indywidualnej może wystąpić dwóch lub więcej zainteresowanych uczestniczących w tym samym zaistniałym stanie faktycznym albo mających uczestniczyć w tym samym zdarzeniu przyszłym (wniosek wspólny). Zainteresowani wskazują wówczas we wniosku wspólnym jeden podmiot, który jest stroną postępowania w sprawie interpretacji. Interpretację indywidualną lub postanowienie w sprawie doręcza się podmiotowi wskazanemu jako strona, natomiast pozostałym zainteresowanym - odpis interpretacji lub postanowienia.

$\mathrm{Z}$ wnioskiem o wydanie interpretacji indywidualnej może wystąpić zamawiający w rozumieniu odpowiedniej ustawy ${ }^{6} \mathrm{w}$ zakresie mającym wpływ na sposób obliczenia ceny w związku z udzielanym zamówieniem publicznym, podmiot publiczny w rozumieniu odrębnej ustawy ${ }^{7}$ i w zakresie mającym wpływ na sposób obliczenia wynagrodzenia w związku z zawieraną umową o partnerstwie publiczno-prywatnym lub zamawiający $\mathrm{w}$ rozumieniu jeszcze innej ustawy ${ }^{8} \mathrm{w}$ zakresie mającym wpływ na sposób obliczenia wynagrodzenia koncesjonariusza wraz $\mathrm{z}$ ewentualną płatnością od zamawiającego w związku z zawieraną umową koncesji na roboty budowlane lub usługi.

Trzeba podkreślić, że interpretacje przepisów prawa podatkowego nie mogą być uznane za indywidualny akt administracyjny, ponieważ nie rozstrzygają o prawach i obowiązkach ich adresatów albo — mówiąc szerzej — nie rozstrzygają władczo o prawach i obowiązkach podmiotów prawa materialnego. Ogólne oraz indywidualne interpretacje przepisów prawa podatkowego stanowią wydawaną udzielaną przez właściwe podmioty będące organami podatkowymi - informację o możliwościach stosowania materialnego prawa podatkowego oraz o związanej z tym wykładni przywołanego prawa. Nie mają też mocy formalnie wiążącej względem zarówno adresatów prawa podatkowego, jak i organów podatkowych ${ }^{9}$.

\section{Zakończenie}

Stosownie do poglądu doktryny na gruncie ustawy Ordynacja podatkowa, a w kontekście jej nowelizacji zgodnie z założeniami Komisji Kodyfikacyjnej

${ }^{6}$ Ustawa z dnia 29 stycznia 2004 roku — Prawo zamówień publicznych (Dz.U. z 2018 r. poz. 1986 ze zm.).

7 Ustawa z dnia 19 grudnia 2008 roku o partnerstwie publiczno-prywatnym (Dz.U. z 2017 r. poz. 1834 ze zm.).

${ }^{8}$ Ustawa z dnia 21 października 2016 roku o umowie koncesji na roboty budowlane lub usługi (Dz.U. z 2016 r. poz. 1920 ze zm.).

9 J. Brolik, Doręczanie indywidualnych interpretacji przepisów prawa podatkowego - znaczenie prawne doręczenia, „Glosa” 2015, nr 1, s. 104. 
Ogólnego Prawa Podatkowego, dla wnioskodawców pragnących uzyskać ochronę w zakresie, w jakim konieczna jest analiza stanu faktycznego, procedura konsultacyjna będzie formą komplementarną wobec dotychczasowego postępowania w sprawie wydania interpretacji indywidualnej prawa podatkowego. W tym ostatnim wypadku stan faktyczny nie jest bowiem badany, lecz jedynie przyjmowany na podstawie opisu zawartego we wniosku podatnika. Procedura jest odpowiedzią na zgłaszane od lat postulaty udzielenia podatnikom legitymacji procesowej do wnioskowania o przeprowadzenie postępowania podatkowego lub kontroli podatkowej, umożliwiające weryfikację prawidłowości samoobliczenia na wnio$\operatorname{sek}^{10}$. Niemniej jednak w obowiązującym i planowanym stanie prawnym mamy lub może będziemy mieli do czynienia z trzema funkcjonującymi niezależnie od siebie instytucjami uregulowanymi w dwóch aktach prawnych rangi ustawowej. W szczególności można w tym zakresie wymienić: decyzję w sprawie skutków podatkowych transakcji w projekcie nowelizacji ustawy Ordynacja podatkowa, decyzję w sprawie interpretacji indywidualnej z ustawy Prawo przedsiębiorców oraz postanowienie w sprawie interpretacji indywidualnej z ustawy Ordynacja podatkowa wydawane przez dyrektora Krajowej Informacji Skarbowej i organy wykonawcze samorządu terytorialnego (czyli interpretacje samorządowe).

Analiza relacji pomiędzy trzema omawianymi instytucjami obowiązującymi w dwu przywołanych aktach, przy funkcjonującej jeszcze w projekcie decyzji w sprawie skutków podatkowych transakcji, prowadzi do kilku wniosków. Przede wszystkim wspólną cechą omawianych instytucji prawnych jest niezależność — każda z nich funkcjonuje osobno i charakteryzuje się samodzielnością proceduralną. Inną ich wspólną cechą jest cel tychże rozwiązań prawnych. Wydaje się, że jest nim w tym względzie wzmożenie ochrony podatnika (przedsiębiorcy) w zakresie skutków podejmowanych decyzji w sferze gospodarczej oraz podatkowej w sytuacji obowiązywania dość zawiłych regulacji prawnych $\mathrm{w}$ tym zakresie oraz inflacji orzecznictwa i wszelkiego rodzaju interpretacji prawa gospodarczego i finansowego (głównie podatkowego).

Jednocześnie jednak pojawia się wątpliwość, czy mnogość tych procedur nie będzie stanowić nadregulacji. Może bowiem zdarzyć się sytuacja dysponowania przez przedsiębiorcę/podatnika kilkoma interpretacjami lub decyzjami wzajemnie się wykluczającymi lub częściowo sprzecznymi, a dotyczącymi tego samego stanu faktycznego. W nawiązaniu do tego należy wskazać, że różnicami pomiędzy postanowieniem interpretacyjnym z Ordynacji podatkowej a decyzją w sprawie skutków podatkowych transakcji jest forma prawna działania organu administracji oraz zakres przedmiotowy, zawężony w wypadku decyzji, a także obowiązek prowadzenia uzgodnień. W zasadzie nie ma innych istotnych różnic. Pytaniem brzmi, czy procedura decyzyjna powinna być wprowadzana, a jeśli tak, to czy nie powinna zostać włączona do procedury postanowieniowej z ustawy Ordynacja

10 S. Babiarz et al., op. cit., s. 658. 
podatkowa. Powstaje dodatkowo kolejne pytanie - o przepisy dotyczące indywidualnej interpretacji na podstawie ustawy Prawo przedsiębiorców w relacji do podobnych przepisów z ustawy Ordynacja podatkowa. Jak wynika z art. 34 ust. 17, w zakresie zasad i trybu udzielania interpretacji przepisów prawa podatkowego zastosowanie mają przepisy Ordynacji podatkowej. Zasady i tryb udzielania interpretacji przepisów prawa podatkowego zostały uregulowane w rozdziale 1a Ordynacji podatkowej, zatytułowanym „Interpretacje przepisów prawa podatkowego", w art. 14a-14s. W tym kontekście nie powinno budzić żadnych wątpliwości, że uzyskanie przez przedsiębiorcę interpretacji przepisów prawa podatkowego będzie regulowane tylko przez Ordynację podatkową ${ }^{11}$. Wydaje się, że również w tym zakresie zasada ta dotyczy podatków samorządowych.

W świetle przeprowadzonych analiz zawsze aktualny w naukach prawnych pozostaje wzgląd na zasadę zupełności oraz zasadę komplementarności przepisów prawnych. Zasada zupełności głosi, że określona sytuacja prawna lub zdarzenie prawne oparte na podobnie zdiagnozowanym stanie faktycznym powinna być oparta na jednolitym lub komplementarnym rozwiązaniu prawnym. $Z$ tym też wiąże się zasada komplementarności prawa. Właśnie przez wzgląd na owe zasady, które są regułami przewodnimi w naukach prawnych i są przydatne w praktyce stosowania prawa, wnioskowałbym o ujednolicenie w omawianym zakresie problematyki indywidualnych interpretacji przepisów prawa. W obecnym stanie prawnym są one bowiem rozproszone i rozdrobnione. Trzeba by w związku z tym dokonać ponownej analizy przydatności i funkcjonalności obowiązujących unormowań prawnych i wysnuć wnioski de lege ferenda w kierunku zinstytucjonalizowania interpretacji indywidualnych $\mathrm{w}$ jednym ośrodku. W tym zakresie pojawiają się cztery istotne pytania: jaki miałby być zakres interpretacji, jakich dziedzin prawa miałby dotyczyć, jak miałby być zorganizowany oraz jaką gwarantowałby ochronę dla wnioskodawcy. Omawiane zagadnienie w określonej części z całą pewnością dotyczy relacji oraz stosunku państwa do przedsiębiorcy i stanowi wyzwanie dla praktyki i nauki. Pytania w tym zakresie pozostawiam otwarte, licząc na merytoryczną i owocną dyskusję na ten temat.

\section{Bibliografia}

Babiarz S., Dowgier R., Etel L., Filipczyk H., Gurba W., Krawczyk I., Kuśnierz W., Łoboda M., Nikończyk A., Nita A., Ogrodowczyk B., Olesińska A., Pietrasz P., Popławski M., Rudowski J., Strzelec D., Taborski G., Zajączkowski A., Nowa Ordynacja podatkowa. Z prac Komisji Kodyfikacyjnej Ogólnego Prawa Podatkowego, Białystok 2017.

11 M. Korzeniewski, P. Tracz, Komentarz do art. 34 ustawy - Prawo przedsiębiorców, SIP LEX 2019. 
Bielecki L., Załatwianie spraw z zakresu działalności gospodarczej, [w:] Konstytucja biznesu. Komentarz, red. M. Wierzbowski, Warszawa 2019.

Brolik J., Doręczanie indywidualnych interpretacji przepisów prawa podatkowego — znaczenie prawne doręczenia, „Glosa” 2015, nr 1.

Korzeniewski M., Tracz P., Komentarz do art. 34 ustawy — Prawo przedsiębiorców, SIP LEX 2019.

\title{
Decision on the tax consequences of transactions in the draft amendment to the Tax Ordinance Act, individual interpretation in the Tax Ordinance Act, and the decision on individual interpretation in the Law of Entrepreneurs
}

\begin{abstract}
Summary
The article discusses three issues - the decision on the tax consequences of transactions in the draft amendment to the Tax Ordinance Act, individual interpretation in the Tax Ordinance Act, and the decision on individual interpretation in the Law of Entrepreneurs. The common feature of these legal institutions is their independence. Each of them functions separately and is characterized by procedural independence. Another common feature is the purpose of these legal solutions. In conclusion, there is a need to re-analyze the usefulness and functionality of current legal regulations and draw conclusions de lege ferenda towards institutionalization of individual interpretations in one center. Four important questions arise in this regard. What would be the scope of the interpretation, what areas of law would it concern, how would it be organized and what protection would it provide for the applicant? The issue discussed certainly concerns the relationship and attitude of the state to the entrepreneur and is a challenge for practice and theory.
\end{abstract}

Keywords: decision on the tax consequences of transactions, Tax Ordinance Act, individual interpretation, decision on individual interpretation, Law of Entrepreneurs. 